
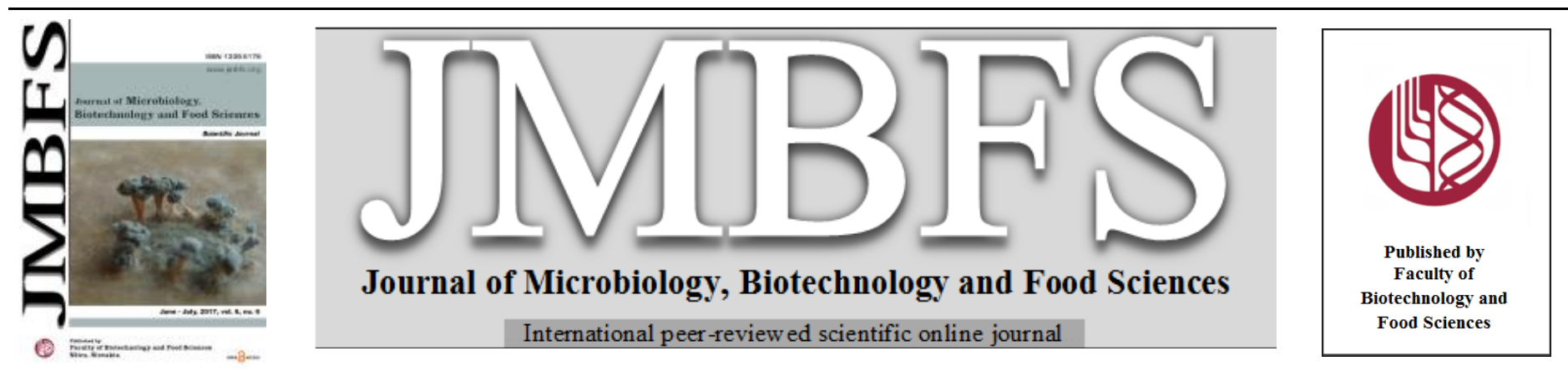

\title{
THE FAMILY OF CHITINASES IN COTTON G. raimondii
}

\section{Akmal M. Asrorov*1, Ildikó Matušiková ${ }^{2}$, Zdenka Gálová ${ }^{3}$, Zuzana Gregorovát, Patrik Mészáros ${ }^{4}$, Surayyo Dalimova ${ }^{5}$, Shavkat Salikhov ${ }^{\text {As }}$}

\author{
$\operatorname{Address}(e s):$ \\ ${ }^{1}$ Laboratory of Proteins and Peptides Chemistry, A.S.Sadykov Institute of Bioorganic chemistry, Academy of Sciences of Uzbekistan, M.Ulughbek Str., 83, Tashkent, \\ Uzbekistan. \\ ${ }^{2}$ Department of Ecochemistry and Radiology, Faculty of Natural Sciences, University of Ss. Cyril and Methodius in Trnava, Hlavná 418, SK-91951 Špačince, \\ Slovakia. \\ ${ }^{3}$ Department of Biochemistry and Biotechnology, Slovak University of Agriculture in Nitra, Tr. Andreja Hlinku 2, 94976 Nitra, Slovakia. \\ ${ }^{4}$ Department of Botany and Genetics, Faculty of Natural Sciences, Constantine the Philosopher University in Nitra, Nábrežie mládeže 91 , 94974 Nitra, Slovakia. \\ ${ }^{5}$ Department of Biology and Soil Sciences, National University of Uzbekistan, Talabalar Shaharchasi, Tashkent, Uzbekistan.
}

*Corresponding author: akmal84a@gmail.com

doi: $\underline{10.15414 / j m b f s .2017 .6 .6 .1284-1289}$

ARTICLE INFO

Received 3. 2. 2017

Revised 20. 4. 2017

Accepted 27. 4. 2017

Published 1. 6. 2017

Regular article OPEN $\partial_{\text {ACCESS }}$

\begin{abstract}
Chitinases are enzymes widely spread in plants with no endogenous substrate and play significant role to lyse the cell walls of many pathogens. Their role in defense is firmly established. Recently, their functions in plants have been extended to response to abiotic stresses and various developmental plant processes. The gene family of chitinases is well characterized in some model species. Few researches on their involvement in cotton defense against pathogens have been reported. Here were investigated Gossypium raimondii genome in the Phytozome database for the presence of homologues. BLAST similarity search, using five chitinase representatives from Arabidopsis belonging to different classes I-V, identified a total of 41 non-redundant chitinase gene sequences in cotton. We analysed them in silico using available bioinformatics software and characterized their basic molecular structures. Signal peptides, carbohydratebinding domains, hinge regions were predicted, molecular weights and expected isoelectric points were calculated. Genes were divided into different chitinase classes based on homology clustering with genes from Arabidopsis. The individual family members were further linked to expression data and/or literary knowledge, which is in relation to cotton rather scarce. Knowledge on chitinase gene family members in cotton provides a basic for further basic-as well as applied cotton research as they are functionally validated.
\end{abstract}

\section{INTRODUCTION}

Plants evolve mechanisms to counter biotic and abiotic stresses. Accumulation of pathogenesis-related (PR) proteins is one of the developed mechanisms highly expressed by plants during the attack by pathogens. Among PR members, chitinases (PR-3) can hydrolyse chitin in the exoskeleton of insects and cell wall of pathogenic fungi, consequently play an important role in the plant defense against those organisms. Chitinases have extensively been studied for their use in different biotechnological programs for plant protection. A number of crops such as tomato, potato, maize, rapeseed, wheat, rice and others have been successfully engineered for resistance either with chitinase alone or in combination with othe PR proteins (Cletus et al. 2013). In recent 10 years was observed an increasing amount of evidence on the role of these enzymes in plant adaptation to abiotic stresses, including drought (Gregorová et al. 2015), toxic metals (Mészáros $\boldsymbol{e}$ al. 2014) and even pesticides (Asrorov et al. 2013). Besides, chitinases play pivotal role in plant morphogenesis and development with impact on growth and stress tolerance. Therefore, research on chitinases in important crop species is of crucial importance.

Breeding stress-tolerant and high-yield cotton might exploit chitinases and other PR proteins since a couple of researchers proved their importance in cotton defense against aphids and mites. For example, three acidic chitinase isozymes (pI in the range 3.7-4.2) from $G$. hirsutum leaves were gradually elicited by $V$. dahliae for 120 hours (Dubery and Slater, 1997), some of them probably inhibited the germination of conidia (Liu et al. 1995). PRs including chitinases likely contribute to restriction of wilting in cotton infected by Verticillium (Bu et al. 2014). Furthermore, elevated activities of chitinases and other PR proteins resulted in reduced population of aphids in cotton (Rajendran et al. 2011), and their inhibition by insecticide treatment resulted in the population growth of spider mites both in greenhouse and field experiments (Szczepaniec et al. 2013). On the other hand, chitinases in cotton are believed to play a role in fiber formation, too (Wiweger et al. 2003).

Plant chitinases are structurally well characterized and are divided into several groups. The class I chitinases have an N-terminal cysteine-rich regions involved in chitin-binding (Iseli et al. 1993). These regions are separated from the catalytic domain by a short proline-rich variable hinge region and the catalytic domain is often followed by a C-terminal extension which is involved in vacuolar targeting (Neuhaus et al. 1991). Class II chitinases have a catalytic domain with a high sequence and structural similarity to those of class I chitinases. However they possess neither the $\mathrm{N}$-terminal cystein-rich region nor the $\mathrm{C}$-terminal extension The main structure of class IV chitinases resembles class I chitinases, but is reduced by few deletions along the carbohydrate-binding domain (CBD) and the catalytic region (Passarinho and deVries 2002). The class III chitinases are similar to class $\mathrm{V}$ chitinases of plant origin and fungal/bacterial chitinases (Graham and Sticklen, 1994). Class V chitinases have a C-terminal extension for vacuolar targeting and may contain CBD as well (Heitz et al. 1994; Ponstein et al. 1994). Class V and III chitinases belong to the family 18 of glycosyl hydrolases whereas all other classes belong to family 19. Chitinases of families 19 and 18 do not share sequence similarity, they have completely different 3-D structures and molecular mechanisms (Suzuki et al. 1999).

Inspite of cotton genome sequence available, the family of chitinases in cotton is low explored. The objective of this work to identify and describe the chitinase genes and their families in $G$. raimondii and link them with corresponding knowledge available in literature.

\section{MATERIAL AND METHODS}

\section{Searching the cotton genome for chitinases}

The cotton genome in the Phytozome database was searched for chitinases using the BLAST program (Table 1). Five chitinase gene representatives from 
Arabidopsis thaliana AT1G56680, AT1G02360, AT3G12500, AT4G19720 and AT5G24090, belonging to classes I-V were used as queries (Passarinho and deVries, 2002). Redundant sequences were removed at $\geq 98 \%$ similarity in amino acid translations. All identified putative chitinases in cotton were back-searched in the NCBI database to prove similarity with chitinases (E value $\leq 10^{-20}$ ). Subsequently, different databases and softwares (Table 1) were used to predict their structural and molecular characteristics such as molecular weight and putative isoelectric points, the presence of individual protein domains and signal peptides (Table 1). Sequence alignment of chitinases from cotton and Arabidopsis was done using ClustalW (Table 1) and evolutionary relationships were observed by viewing Cladogram or Phylogram in the program. The phylogenetic tree was built using software (www.ebi.ac.uk/Tools/msa) Maximum likelihood method was used. Available data on chitinase gene expression in cotton were obtained from the database plex (Table 1).

Table 1 List of used databases and bioinformatic softwares

\begin{tabular}{lc} 
Phytozome & http://www.phytozome.jgi.doe.gov/ \\
National Center for & $\underline{\text { http://www.ncbi.nlm.nih.gov/ }}$ \\
Biotechnological Information & $\underline{\text { Moltp://web.expasy.org/compute pi/ }}$ \\
Point & $\underline{\text { http://www.cbs.dtu.dk/services/SignalP/ }}$ \\
Signal peptide & $\underline{\text { http://web.expasy.org/decrease_redunda }}$ \\
Decrease redundancy & $\underline{\mathrm{hcy/}}$ \\
Clustalw///www.ebi.ac.uk/Tools/msa/clustal & $\underline{\mathrm{w} 2 /}$ \\
Expression data/PLEXdb & $\underline{\text { www.plexdb.org/modules/tools/plexdb }}$ \\
Arabidopsis Genome database & $\underline{\text { blast.php }}$ \\
\hline
\end{tabular}

\section{Protein Extractions and Analysis}

We studied total chitinase activity of cotton plant leaves in comparison with other plant materials. For that lyophilized, fully developed mature leaves were collected from Gossypium hirsutum, Malva sylvestris, Morus multicaulis, Populus, Ligustrum vulgare and Rumex obtusifolius, growing in close distance with the same ecological parameters in the locality of Tashkent, Uzbekistan (GPS coordinates: $41^{\circ} 15^{\prime} 52.7400^{\prime \prime} \mathrm{N}$ and $69^{\circ} 12^{\prime} 58.5720^{\prime \prime}$ E). Tissue material (500 g) was ground with liquid nitrogen using a mortar and pestle. After grinding, proteins were isolated and assayed for chitinase activity as described previously (Reissig et al. 1955). The activity of the enzyme was expressed as mmol of $\mathrm{N}$ acetyl glucoseamine amount hydrolyzed for 2 hours.

\section{RESULTS AND DISCUSSION}

Mature cotton leaves contain proteins with chitinolytic activity. This activity is comparable with that measured in leaves of malva (Malva sylvestris), white mulberry (Morus multucaulis) and poplar (Populus), but lower than in wild privet (Ligustrum vulgare) or bitter dock (Rumex obtusifolius) (Fig. 1).

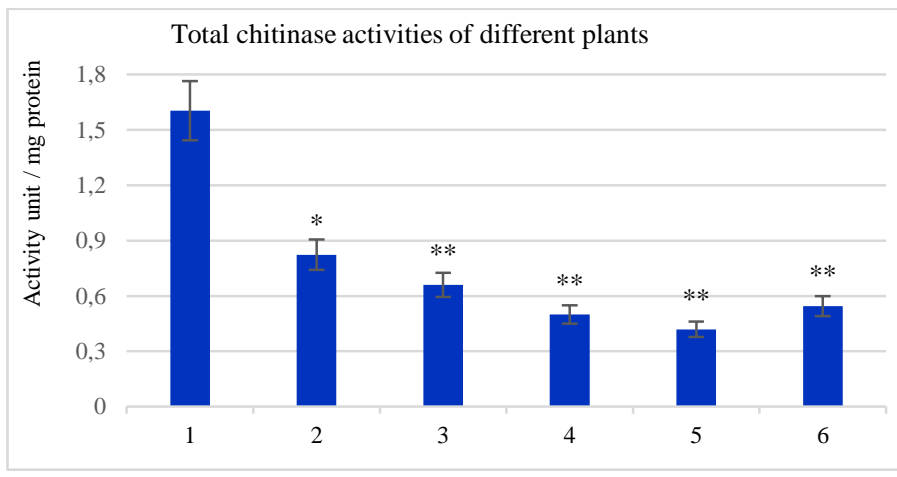

Figure 1 Variability of total chitinase activity in mature leaves of different plant species such as Rumex obtusifolius (1), Ligustrum vulgare (2), Populus alba (3), Morus multicaulis (4), Malva Sylvestris (5) and Gossypium hirsutum (6). (The error bars were calculated based on the four replicates with standard deviation, “*”: significant difference at $\mathrm{P}<0.1$; “**”: significant difference at $\mathrm{P}<0.05$ )
We have measured the overall activity of chitinases in cotton. The obtained values are, however, hardly indicative since results are from the activities of several individual isoforms of different activity, regulation and function. The activity of chitinases varies among plant species, but also depends on developmental stage and even plant organ (Gregorová et al. 2015). Nevertheless, their total activity in pea was shown to coincide with metal tolerance (Metwally et al. 2005). Moreover, not only absolute activity values but kinetics of individual chitinase isoforms can coincide with plant tolerance to stresses (Mészáros et al. 2013), hence detailed study of corresponding gene family might be very useful for plant improvement.

The measured activities are the results of action of several different isoforms encoded by the members of chitinase family. Here, the genome of G. raimondi and G. hirsutum were searched with chitinases from Arabidopsis thaliana for presence of expressed and putative gene homologues using the BLAST program in Phytozome and NCBI database. This search revealed a total of 43 gene sequences annotated as chitinases, of which 2 were removed as redundant using a software. A total of 41 non-redundant putative chitinases were detected in cotton. Their calculated molecular weights varied in the range of 24.9-49.8 kDa. More than half of them (29 out of 41) were predicted as acidic with the pI lower than 6.5 , and only four chitinases were found to have $\mathrm{pI}$ in neutral range and 9 chitinases are possibly basic. Clustering with chitinase representatives from $A$. thaliana and the cotton chitinase class VII ( $\mathbf{L i}$ and Liu 2003) sorted the cotton chitinases into six classes (Figure 2).

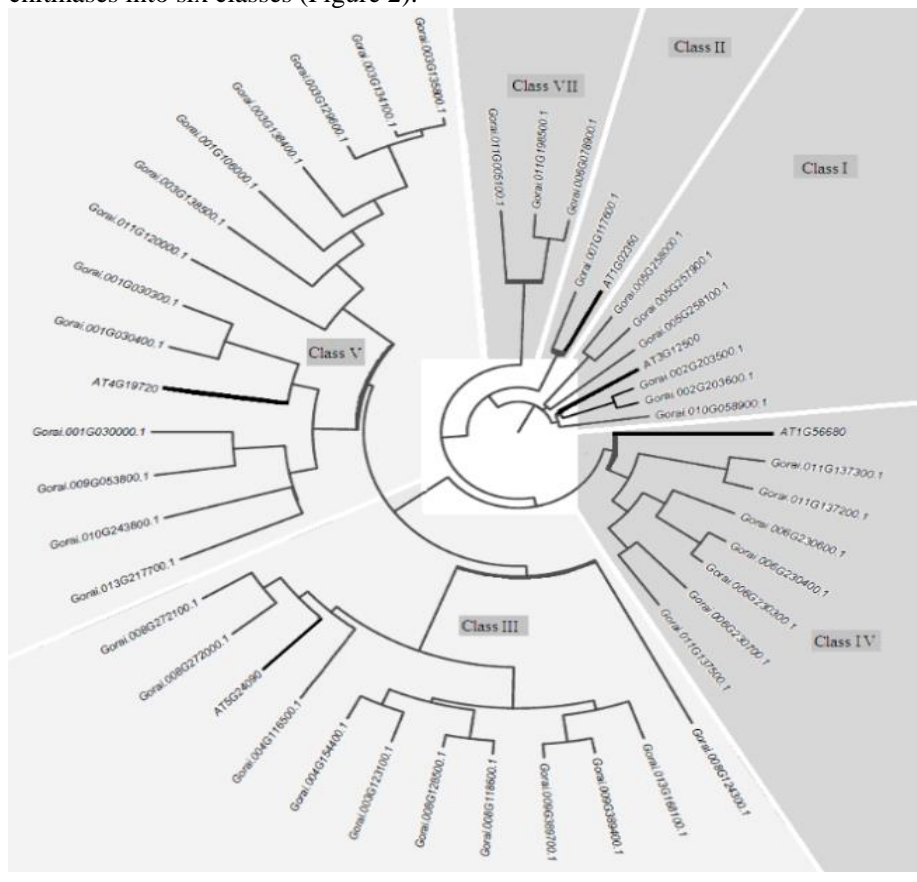

Figure 2 Dendrogram of cotton chitinases based on amino acid sequence alignment with representatives of genes belonging to classes I-V from $A$ thaliana. Representatives of genes from A. thaliana are described in bold. In light grey background, genes of Family GH 18 are shown. Genes of Family GH 19 are indicated in dark grey background.

This distribution fits with expected structural data. Translations of 17 identified cotton chitinases contain a Glyco_hydro_19 domain (GH19) (Family 19 chitinases), and 24 chitinases possess a Glyco_hydro_18 domain (GH18) typical for the family 18 chitinases. The family 19 chitinases comprised classes I, II, IV, VII and included 17 putative genes, and the family 18 chitinases possessed 11 genes of class III and 13 of class V chitinases (Figure 2 and 3). A putative signal peptide (SP) is present in 37 chitinase genes (Figure 3). A carbohydrate-binding domain was identified in only some of Family 19 chitinases, namely in six class IV and three class I chitinase genes (Figure 3). Among them, a proline rich, socalled hinge region was found in two out of three class I, and four of six class IV chitinases (Figure 3). 


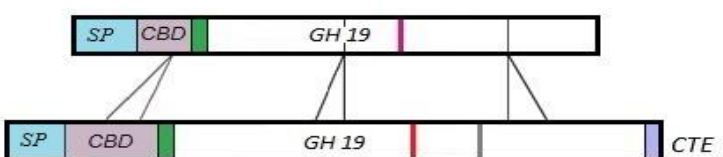

\begin{tabular}{|l|l|l|l|}
\hline$S P$ & GH 19 & & \\
\hline
\end{tabular}

\begin{tabular}{|l|l|l|l|l|}
\hline$S P$ & & GH 19 & & CTE \\
\hline
\end{tabular}

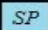

GH 18

$S P$

$P$ GH 18

B

\begin{tabular}{|c|c|c|c|c|}
\hline & $\mathrm{Nu}$ & mber of genes & & Abundance of \\
\hline & & & & \\
\hline IV & 9 & 5 & 7 & 0.171 \\
\hline I & 1 & 10 & 6 & 0.146 \\
\hline II & 4 & 3 & 1 & 0.024 \\
\hline VII & - & - & 3 & 0.073 \\
\hline III & 1 & 13 & 11 & 0.268 \\
\hline V & 9 & 5 & 13 & 0.317 \\
\hline
\end{tabular}

Figure 3 Primary structural maps of chitinase (class I - VII) genes found in cotton (G. raimondii) genome and the number of their representants in different plant species. SP - Signal peptide; CBD - carbohydrate-binding domain; - Hinge region; GH 18 and $G H 19$ Glycohydrolase domain 18/19, CTE- C-terminal extension; $\triangle$ Deletions; with red lines YNYG motifs are represented in classes I, II, and VII; dark grey lines in class I and class II chitinases stands for WFWM motifs; CRGP motif in class IV chitinases is noted in pink line; EVAAF motifs are marked with a violet line in class VII chitinases

We identified and characterized to some extent in silico a total of 41 chitinase genes in the genome of cotton. This number is higher comparing with 24 genes described in the model plant A. thaliana (Passarinho and de-Vries, 2002) or the 37 genes in poplar (P.trichocarpa) (Jiang et al. 2013) (Figure 3). Since the number of chitinase genes among dicotyledonous and monocotyledonous plant species is expected to be comparable (Yokoyama and Nishitani 2004), the observed discrepancy is likely because of available rapidly developing bioinformatic tools (Figure 3). Consequently, the currently described gene families in individual species might in reality still be larger and incomplete.

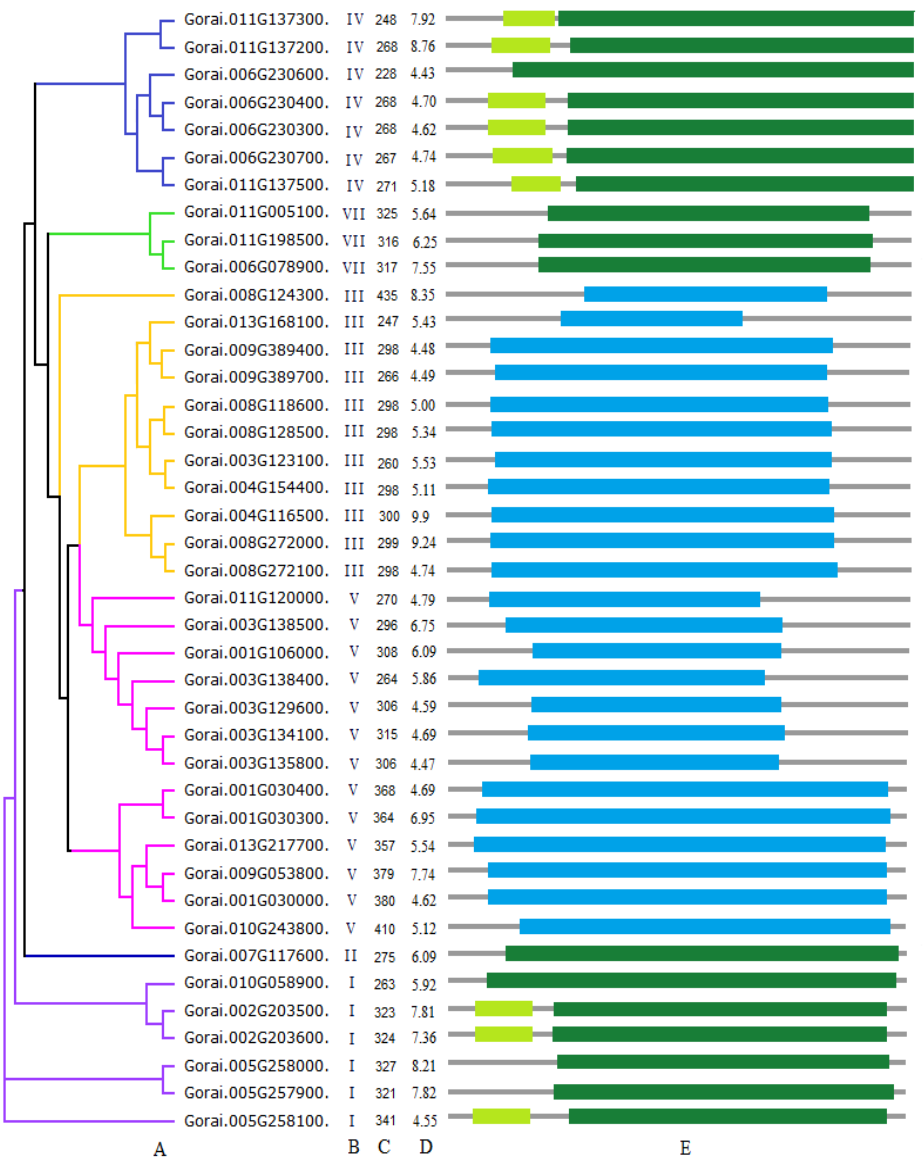

Figure 4 Phylogenetic relationships among G. raimondii chitinase genes and their protein structures: A - Phylogenetic tree; B - Chitinase class; C - number of amino acids in the enzyme molecule: D - Putative isoelectric points of enzymes E - Domains: - Glycosyl hydrolase Family 18; - Glycosyl hydrolase Family 19; - Carbohydrate binding domain;
Calculated molecular weights of all encoded cotton chitinases were in the range of 24.9-49.8 kDa which are similar to those found in Arabidopsis 23.3-46.9 kDa (Passarinho and deVries 2002).

Intron-exon structures of cotton chitinases resemble some similarities with respect to enzyme classification (Figure 4). All class I chitinases have 2 introns and 3 exons. All class IV chitinases (except for the Gorai.011G137300) have 1 intron and 2 exons. In contrast, gene structures of Family 18 chitinases were more variable. Seven of eleven class III members lack any intron; 3 genes possess one intron and one gene (Gorai.008G124300) contains 7 introns. Seven of thirteen cotton class $\mathrm{V}$ chitinase genes possess one intron. Five of them have a relatively conserved position of intron at the beginning of the gene. The other six class $\mathrm{V}$ family members lack any intron.

The chitinase genes in the Phytosome database were assigned to the five typical structural classes, and clustering with chitinases from well-described Arabidopsis confirmed this distribution (Figure 2). In addition to these five typical classes, a class VII chitinase has been described and characterized by $\mathbf{L i}$ and Liu (2003) We identified two more chitinases showing high sequence similarity to the class VII chitinase found in the cotton genome (Figure 2 and 4). Typically, these enzymes lack the CBD ( $\mathbf{L i}$ and Liu 2003). While two of them (Gorai011G005100 and Gorai006G078900) show responsiveness to abiotic stresses (Christianson et al. 2002; Padmalatha et al. 2012; Table 2), the third (Gorai.011G198500) has been suggested to play a role in fiber development (Zhang D et al, 2004). 

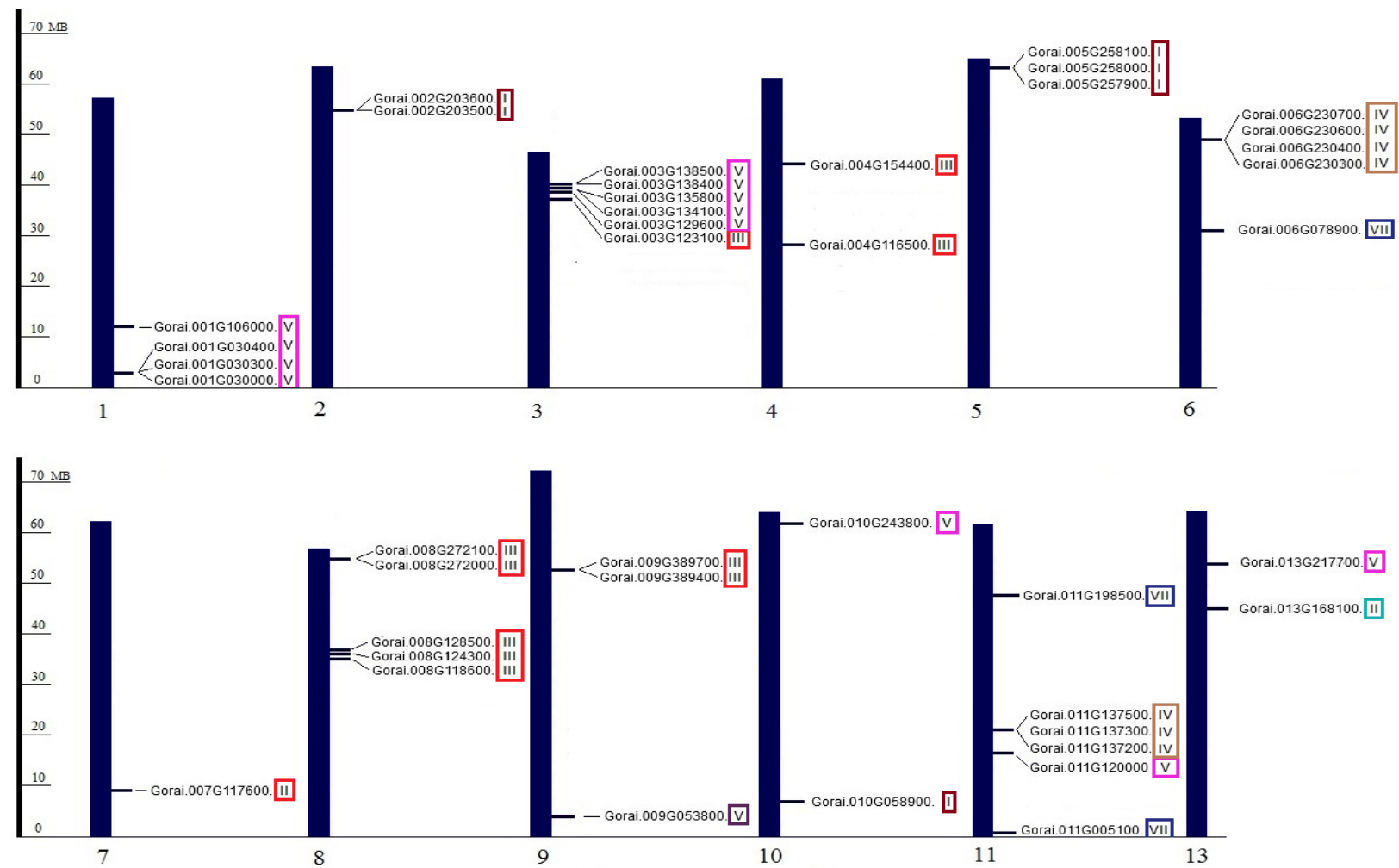

Figure 5 Genomic localization of G. raimondii chitinase genes. Transcript names and chitinase classes (in Roman digits) are given in front of localization. Numbers of chromosomes are indicated under the columns. Classes of chitinases are shown in quadrangles.

We retrieved data on the localization of chitinase genes in chromosomes of $G$ raimondii from the Phytozome database (Figure 5). The largest numbers of chitinase genes were located on the chromosomes 3, 11 (6 genes) and 6, 8 (5 genes). Many genes belonging to similar classes are co-localized. Only class III chitinases are located on the chromosomes 4 and 8, class I chitinases are only present on the chromosomes 2 and 5 , while only class $\mathrm{V}$ chitinases were identified on the chromosome 1 . On the other hand, clusters of chitinase genes (small regions of chromosomes where several genes are co-located) were identified on the cotton chromosomes 1, 5, 6 and 11. On the chromosomes 6 and 11 there were two clusters of class IV chitinases, three class I chitinases were clustered on the chromosome 5 , and three class $\mathrm{V}$ chitinases are clustered on the chromosome 1 .

The chitinase genes in cotton are distributed along the almost entire genome except for the single chromosome 12 (Figure 5). This distribution is relatively even comparing with other species. For instance in A.thaliana all the 24 chitinases were found in five chromosomes (Passarinho and de Vries, 2002), while the largest number of chitinases belonged to chromosomes 2 (6 chitinases) and 4 (9 chitinases). The majority (30 of 37) of chitinase genes in P. trichocarpa were positioned on the chromosomes 8 of 19 (Jiang et al. 2013). On the other hand, co-localisation of similar class chitinases in cotton appears as a common feature. Similar pattern was observed in P. trichocarpa chitinases, where the class I chitinases were localized on chromosomes 4 and 9 , and class $V$ chitinases were located on chromosomes 6 and 18 (Jiang et al. 2013). Similarly, in A. thaliana the class IV chitinases were found on chromosome 2 and Class V genes were positioned on chromosome IV (Passarinho and de Vries, 2002).

Since expression data are still unavailable for cotton in the Phytozome database, the chitinase genes identified were used as queries for similarity search of the PLEXdb database (Cotton PLEX). Expression data could be retrieved for a total of 8 cotton chitinase genes (Table 2)

Microarray gene expression data were obtained on leaves and roots of experimental cotton plants in the context of flooding (Christianson et al. 2009) and drought conditions (Rodriguez et al. 2014; Padmaltaha et al. 2012) (Table 2). A clone with high sequence similarity to the class IV chitinases Gorai.006G230700 was strongly responsive to drought in greenhouse condition (Padmalatha et al. 2012) and significantly lower value was true in field experiments (Rodriguez et al. 2014), however remained unaffected in floodexposed leaves and roots in a field study (Christianson et al. 2009).

Table 2 Expression data of chitinases in the PLEX $d b$ (www.plexdb.org/modules/tools/plexdb blast.php)

\begin{tabular}{|c|c|c|c|c|c|c|c|c|c|}
\hline \multirow{3}{*}{ Phytozome name } & \multirow[b]{3}{*}{ Class } & \multicolumn{4}{|c|}{ Christianson et al. 2009} & \multirow{2}{*}{\multicolumn{2}{|c|}{$\begin{array}{l}\text { Rodriguez et al. } 2014 \\
\text { Leaf (field experiment) }\end{array}$}} & \multirow{2}{*}{\multicolumn{2}{|c|}{$\begin{array}{c}\text { Padmalatha } \text { et al. } 2012 \\
\text { Leaf (Greenhouse) } \\
\end{array}$}} \\
\hline & & \multicolumn{2}{|c|}{ Root } & \multicolumn{2}{|c|}{ Leaf } & & & & \\
\hline & & Control & Flooded & Control & Flooded & Control & Drought & Control & Drought \\
\hline Gorai.005G257900.1 & $\mathrm{I}$ & 4.8 & 2.03 & 1.22 & 1.39 & 4.9 & 4.31 & 4.09 & 2.78 \\
\hline Gorai.005G258100.1 & I & 10.05 & 11.82 & 7.98 & 6.29 & 7.03 & 7.49 & 7.4 & 9.0 \\
\hline Gorai.008G272000.1 & III & 11.45 & 11.68 & 5.47 & 5.87 & 7.37 & 7.04 & 8.16 & 8.9 \\
\hline Gorai.008G272100.1 & III & 5.95 & 6.95 & 5.86 & 6.5 & 7.34 & 6.82 & 9.49 & 11.78 \\
\hline Gorai.008G124300.1 & III & 8.42 & 7.58 & 7.02 & 6.68 & 7.16 & 7.88 & 8.85 & 8.76 \\
\hline Gorai.006G230700.1 & IV & 4.29 & 4.92 & 3.35 & 3.1 & 5.48 & 3.95 & 2.72 & 5.07 \\
\hline Gorai.011G005100.1 & VII & 5.98 & 5.73 & 3.85 & 2.43 & 5.84 & 4.01 & 4.9 & 3.97 \\
\hline Gorai.006G078900.1 & VII & 3.54 & 2.27 & 1.62 & 1.26 & 3.44 & 4.16 & 5.17 & 0.8 \\
\hline
\end{tabular}

Genes identified as responsive to given stress types are indicated bold

We detected six class I chitinase gene in cotton (Figure 4). One of them (Gorai.005G257900) has been reported as affected in flooded roots and in drought stressed leaves (Table 1; Padmalatha et al. 2012). The other two class I chitinases (Gorai.010G058900 and Gorai.002G203600) have been described as defensive and inducible by SA and ethylene (Hudspeth et al. 1996; Levorson and Chlan, 1997, respectively). Previously, relatively low number of class I chitinase was identified in Arabidopsis as active in roots and at lower levels in leaves and flowers of aging plants (Passarinho et al. 2002).
A single class II chitinase gene in cotton contradicts the relatively higher number of identified class II chitinases in other plant species (Figure 2 and 3). This class of genes might have evolutionary evolved from class I chitinases and was also described for role during defense (Kirsch et al. 1993; Ponath et al. 2000; Meins et al. 1994). On the contrary, surprisingly high number of class III chitinases was identified in cotton, similarly as in poplar but unlike in A. thaliana. The three experimentally studied class III cotton genes are probably involved in the processes other than adaptation to abiotic stresses (Table 2). The single class III 
chitinase in Arabidopsis was induced by fungi, but not wounding, ethylene or SA (Samac and Shah 1991).

Seven class IV chitinases were identified in cotton. One of them (Gorai.006G230700) was induced in leaves exposed to drought (Table 2, Padmalatha et al. 2012), and another (Gorai.011G137500) was found induced in wilting leaf (Wang et al. 2011). Class IV chitinases in other plant species were proposed to be associated with plant resistance against fungi (Lange et al. 1996; Nielsen et al. 1994), viruses, and also abiotic stresses such as heavy metals and UV irradiation (Margis Pinhero et al. 1993). However Passarinho and de-Vries (2002) suggested that class IV chitinases are involved in developmental processes rather than in defense.

Thirteen cotton chitinases belong to class V enzymes. Specific function for this rather diverse group of chitinases has not yet been attributed. They are suggested to play a role in plant defense as well as development (Heitz et al. 1994 Melchers et al. 1994). Two class V chitinase genes in cotton together with class II chitinase were significantly upregulated in cotton roots in response $V$. dahliae and significantly increased following treatment with jasmonic acid and $\mathrm{H}_{2} \mathrm{O}_{2}$. Authors suggested that these genes may be involved in plant resistance to stress (Xu et al. 2016)

For some of the chitinase classes a typical role has been assigned. Most typically, antifungal activity has been attributed to class I and II chitinases (Neuhaus $\boldsymbol{e t}$ al. 1191) by hydrolyzing the cell walls of plant pathogenic fungi (Wargo PM 1975), and/or by releasing elicitors of defense reactions (Hadwiger and Beckman 1980). Furthermore, class I and class II chitinases were linked with antifreeze activity in Secale cereale (Pihakaski-Maunsbach et al. 2001; Nakamura et al. 2008), and salt-adaptation in tobacco (Nicotiana tabacum) (Yun et al. 1996). The functional differences between individual (cotton) chitinase classes are, however, not clear since chitinases of separate classes can reflect different chitin recognition levels. For example, Sasaki et al. (2006) demonstrated that class and class III chitinases recognize three contiguous $\mathrm{N}$-acetyl glucose amine residues in different subsites. Furthermore, available expression data indicate that some cotton chitinases of different classes might have overlapping functions. For instance, class I, IV and VII chitinases might be defense-related due to responsiveness to several different abiotic stresses, ethylene or the stress hormone salicylic acid (Chlan and Bourgeois 2001; Nielsen et al. 1994; Li and Liu 2003). In the past decade increasing amount of evidence indicates involvement of chitinases in abiotic stress like metals (Békésiová et al. 2008) cold and spring hardening (Zur et al, 2014), drought (Gregorová et al. 2015) However, these functions have not been attributed to a particular chitinase clas (Stintzi et al. 1993). Researches that are more recent prove that chitinases are activated in cotton upon application of commonly used pesticides (Asrorov $\boldsymbol{e t}$ al. 2013; Rajendran et al. 2011; Szczepaniec et al. 2013). On the other hand, class IV chitinases have been suggested as markers of embryogenesis (Wiweger $\boldsymbol{e t}$ al. 2003). In cotton the chitinase gene corresponding to Gorai.011G198500 has been identified ( $\mathbf{L i}$ and Liu 2003) as not similar to any of the typical plant chitinase classes I-VI (Neuhaus et al. 1996). This unique chitinase, similar to class I and class II chitinases to only $30 \%$, was defined as belonging into a separate class (class VII chitinase), and is abundant in fibers and in the seedling roots ( $\mathbf{L i}$ and Liu 2003). More detailed structural and expression analyses suggested that the two closely related cotton genes, GhCTL1 and GhCTL2, can be preliminarily classified as chitin binding lectins. They likely lack hydrolytic activity, while the chitinase activity in fiber is attributable to the expression of authentic chitinases along with putatively non-hydrolytic GhCTL1/GhCTL2 (Zhang et al. 2004) These specific cotton chitinase initiates fiber wall thickening via the deposition of helical cellulose microfibrils in secondary walls (Zhang et al. 2004), but inducibility with salicylic acid and ethylene indicates additional role in defense (Li and Liu 2003; Hudspeth et al. 1996; Levorson and Chlan et al. 1997). The exact mechanism of action of these genes in fiber formation, however, remains to elucidate.

\section{CONCLUSION}

In summary, we identified the members of chitinase gene family in cotton using bioinformatics tools. The available genome data enable a more detailed analysis of cotton chitinase genes both in silico as well as experimentally. Especially the gene expression data have to be extended in near future to improve our knowledge on the pivotal role of chitinases not only in processes of adaptation to environment, but also in important developmental processes like fiber formation. The obtained results can be a valuable basis for the functional studies of these gene family members in basic- as well as applied cotton research.

\section{REFERENCES}

Asrorov A, Sultanova E, Veshkurova O, Sattarov N, Khodjayev Sh, Salikhov Sh 2013. Effects of different classes of insecticides on the activity of hydrolases in cotton plant leaves. American-Eurasian Journal of Agricultural \& Environmental Sciences, 13(3), 296-300. http://dx.doi.org/10.5829/idosi.aejaes.2013.13.03.1926 Bu, B., Qiu, D., Zeng, H., Guo, L., Yuan, J., \& Yang X. 2014. A fungal protein elicitor PevD1 induces Verticillium wilt resistance in cotton. Plant Cell Reports, 33(3), 461-470. http://dx.doi.org/10.1007/s00299-013-1546-7
Chlan, C. A., \& Bourgeois, R. P. 2001. Class I chitinases in cotton (Gossypium hirsutum): characterization, expression and purification. Plant Science, 161(1), 143-154. http://dx.doiorg/10.1016/S0168-9452(01)00398-3

Christianson, J. A., Llewellyn, D. J., Dennis, E. S., \& Wilson, I. W. 2009. Global gene expression responses to waterlogging in roots and leaves of Cotton (Gossypium hirsutum L.). Plant Cell Physiology, 51(1), 21-37. http://dx.doi.org/10.1093/pcp/pcp163

Cletus, J., Balasubramanian, V, Vashisht, D., \& Sakthivel, N. 2013. Transgenic expression of plant chitinases to enhance disease resistance. Biotechnology Letters, 35(11), 1719-1732. http://dx.doi.org/10.1007/s10529-013-1269-4

Dubery, I. A., Slater, V. 1997. Induced Defence Responses in Cotton Leaf Disks by Elicitors from Verticillium dahliae. Phytochemistry, 44(8), 1429-1434 http://dx.doi.org/10.1016/S0031-9422(96)00635-8

Ebrahim, S., Usha, K., \& Singh, B. 2011. Pathogenesis Related (PR) Proteins in Plant Defense Mechanism. In: A. Méndez-Vilas (eds.) Science against microbial pathogens: communicating current research and technological advances. $3 \mathrm{rd}$ edn. Badajoz, Spain, Formatex Research Centre Publisher. p. 1043-1054.

Graham, L. S., Sticklen, M. B. 1994. Plant chitinases. Canadian Journal of Botany, 72, 1057-1083.

Gregorová, Z., Kováčik, J., Klejdus, B., Maglovski, M., Kuna, R., Hauptvogel, P., \& Matušíkova, I. 2015. Drought-Induced Responses of Physiology, Metabolites, and PR Proteins in Triticum aestivum. Journal of Agricultural and Food Chemistry, 63(37), 8125-8133, http://dx.doi:10.1021/acs.jafc.5b02951

Hadwiger, L. A., Beckman, J. M. 1980. Chitosan as a component of peaFusarium solani interactions. Plant Physiology, 66(2), 205-211. http://dx.doi:10.1104/pp.66.2.205

Hamid, R., Khan, M. A., Ahmad, M., Ahmad, M. M., Abdin, M. Z., Musarrat, J., \& Javed, S. 2013. Chitinases: An update. Journal of Pharmacy and Bioallied Sciences, 5(1), 21-29. http://dx.doi:10.4103/0975-7406.106559

Heitz, T., Segond, S., Kauffmann, S., Geoffroy, P., Prasad, V., Brunner, F., Fritig, B., Legrand, M. 1994. Molecular characterization of a novel tobacco pathogenesis-related (PR) protein: a new plant chitinase/lysozyme. Molecular and General Genetics, 245(2), 246-254. http://dx.doi.org/10.1007/BF00283273

Hudspeth, R. L., Hobbs, S. L., Anderson, D. M., \& Grula, J. W. 1996. Characterization and expression of chitinase and 1,3-beta-glucanase genes in cotton. Plant Molecular Biology, 31(4), 911-916. http://dx.doi.org/10.1007/BF00019478

Iseli, B., Armand, S., Boller, T., Neuhaus, J. M., \& Henrissat, B. 1996. Plant chitinases use two different hydrolytic mechanisms. FEBS Letters, 382(1-2), 186188.

Jiang, G., Huang, R. F., Song, J. L., Huang, M. R., \& Xu, L. A. 2013 Genomewide analysis of the chitinase gene family in Populus trichocarpa Journal of Genetics, 92(1), 121-125. http://dx.doi.org/10.1007/s12041-013 0222-6

Keen, N. T., Dawson, W. O. 1192. Pathogen avirulence genes and elicitors of plant defense. In: Boller T., Meins F. (eds.) Genes Involved in Plant Defense, New York, Springer-Verlag. p. 85-114.

Kim, Y. S., Lee, J. H, Yoon, G. M., Cho, H. S., Park, S. W., Suh, M. C., Choi, D., Ha H. J., Liu, J. R., Pai, H. S. 2000. CHRK1, a chitinase-related receptor-like kinase in tobacco. Plant Physiology, 123(3), 905-916. http://dx.doi.org/10.1104/ pp.123.3.905

Lange, J., Mohr, U., Wiemken, A., Boller T., \& Vogeli-Lange, R. 1996 Proteolytic processing of class IV chitinase in the compatible interaction of bean roots with Fusarium solani. Plant Physiology, 111(4), 1135-1144 http://dx.doi:10.1104/pp.111.4.1135

Levorson, J. P., Chlan, C. A. 1996. Isolation of a genomic DNA clone from Gossypium hirsutum with high similarity to Class I endochitinase plant sequences (Accession No.U60197)(PGR96-054). Plant Physiology, 111, 1354.

Levorson, J. P., Chlan, C. A. 1997. Cloning of an Ethylene-Responsive Chitinase from Cotton (Accession No.U78888) (PGR97-034). Plant Physiology, 113, 665.

Li, J., Liu, J. Y. 2003. A Novel cotton gene encoding a new class of chitinase Acta Botanica Sinica, 45(12), 1489-1496.

Liu, R. J., Li, H. F., Shen. C. Y., \& Chiu, W. F. 1995. Detection of pathogenesis related proteins in cotton plants. Physiological and Molecular Plant Pathology, 47(6), 357-363.

Margis-Pinheiro, M., Martin, C., Didierjean, L., \& Burkard, G. 1993. Differential expression of bean chitinase genes by virusinfection, chemical treatment and UV irradiation. Plant Molecular Biology, 22(4), 659-668.

Meins, F., Fritig, B., Linthorst, H. J. M., Mikkelsen, J. D., Neuhaus, J. M., \& Ryals, J. 1994. Plant chitinase genes. Plant Molecular Biology Reporter, 12, 22 28.

Metwally, A., Safronova, V. I, Belimov, A. A., \& Dietz, K. J. 2005. Genotypic variation of the response to cadmium toxicity in Pisum sativum. Journal of Experimental Botany, 56, 167-178.

Nakamura, T., Ishikawa, M., Nakatani, H., \& Oda, A. 2008. Characterization of cold-responsive extracellular chitinase in bromegrass cell cultures and its 
relationship to antifreeze activity. Plant Physiology, 147(1), 391-401. http://dx.doi.org/10.1104/pp.106.081497

Neuhaus, J. M., Sticher, L., \& Meins, F (Jr)., Boller, T. 1991. A short C-termina sequence is necessary and sufficient for the targeting of chitinases to the plant vacuole. Proceedings of the National Academy of Sciences USA, 88(22), 1036210366. http://dx.doi.org/10.1073/pnas.88.22.10362

Nielsen, K. K., Bojsen, K., Roepstorff, P., \& Mikkelsen, J. D. 1994. A hydroxyproline-containing class IV chitinase of sugar beet is glycosylated with xylose. Plant Molecular Biology, 25(2), 241-257.

Padmalatha, K. V., Dhandapani, G., Kanakachari, M., Kumar, S., Dass, A., Patil, D. P., Rajamani, V., Kumar, K., Pathak, R., Rawat, B., Leelavathi, S., Reddy, P. S., Jain, N., Powar, K. N., Hiremath, V., Katageri, I. S., Reddy, M. K., Solanke, A. U., Reddy, V. S., \& Kumar, P. A. 2012. Genome-wide transcriptomic analysis of cotton under drought stress reveal significant down-regulation of genes and pathways involved in fibre elongation and up-regulation of defense responsive genes. Plant Molecular Biology, 78(3), 223-246. http://dx.doi.org/10.1007/s11103-011-9857-y

Passarinho, P. A., deVries, S. C. 2002. Arabidopsis Chitinases: a Genomic Survey. The Arabidopsis Book, American Society of Plant Biologists. p. 1-25.

Pihakaski-Maunsbach, K., Moffatt, B., Testillano, P., Risueno, M., Yeh, S., Griffith, M., \& Maunsbach, A.B. 2001. Genes encoding chitinase-antifreeze proteins are regulated by cold and expressed by all cell types in winter rye shoots. Physiologia Plantarum, 112(3), 359-371. http://dx.doi.org/10.1034/j.13993054.2001.1120309.x

Ponath, Y., Vollberg, H., Hahlbrock, K., Kombrink, E. 2000. Two differentially regulated class II chitinases from parsley. Biological Chemistry, 381(8), 667-678. http://dx.doi.org/10.1515/BC.2000.087

Ponstein, A. S., Bres-Vloemans, S. A., Sela-Buurlage, M.B., vanden Elzen, P. J., Melchers, L. S., \& Cornelissen, B. J. 1994. A novel pathogen- and woundinducible tobacco (Nicotiana tabacum) protein with antifungal activity. Plant Physiology, 104(1), 109-118. http://dx.doi.org/10.1104/pp.104.1.109

Rajendran, L., Ramanathan, A., Durairaj, C., \& Samiyappan, R. 2011 Endophytic Bacillus subtilis enriched with chitin offer induced systemic resistance in cotton against aphid infestation. Archives of Phytopathology and Plant Protection,_14, 1375-1389.

Reissig, J. L., Strominger, J. L., \& Leloir, L. F. 1955. A Modified Colorimetric method for the estimation of $\mathrm{N}$-acetylamino sugars. Journal of Biological Chemistry, 217(2), 959-966.

Rodriguez-Uribe, L., Abdelraheem, A., Tiwari, R., Sengupta-Gopalan, C. Hughs, S. E., \& Zhang, J. 2014. Identification of drought-responsive genes in a drought tolerant cotton (Gossypium hirsutum L.) cultivar under reduced irrigation field conditions and development of candidate gene markers for drought tolerance. Molecular Breeding, 34(4), 1777-1796. http://dx.doi.10.1007/s11032-014-0138-8

Samac, D. A., Hironaka, C. M., Yallaly, P. E., \& Shah, D. M. 1990. Isolation and characterization of the genes encoding basic and acidic chitinase in Arabidopsis thaliana. Plant Physiology, 93(3), 907-914.

Samac, D. A., Shah, D. M. 1991. Developmental and pathogen-induced activation of the Arabidopsis acidic chitinase promoter. Plant Cell, 3, 1063-1072. http://dx.doi.org/10.1105/tpc.3.10.1063

Sasaki, C., Varum, K. M., Itoh, Y., \& Fukamizo, T. 2006. Rice chitinases: sugar recognition specificities of the individual subsites. Glycobiology, 16(12), 1242 1250. http://dx.doi.org/10.1093/glycob/cwl043

Stintzi, A., Heitz, T., Prasad, V., Wiedemann-Merdinoglu, S., Kauffmann, S., Geoffroy, P., Legrand, M., \& Fritig, B. 1993. Plant 'pathogenesis related' proteins and their role in defense against pathogens. Biochimie, 75(8), 687-706. http://dx.doi.org/10.1016/0300-9084(93)90100-7

Suzuki, K., Taiyoji, M., Sugawara, N., Nikaidou, N., Henrissat, B., \& Watanabe, T. 1999. The third chitinase gene (chiC) of Serratia Marcescens 2170 and the relationship of its product to other bacterial chitinases. Biochemical Journal, 343(3), 587-596.

Szczepaniec, A., Raupp, M. J., Parker, R. D., Kerns, D., \& Eubanks, M. D. 2013 Neonicotinoid insecticides alter induced defenses and increase susceptibility to Spider Mites in distantly related crop plants, PLoS ONE. 8(5). http://dx.doi.org/10.1371/journal.phone.0062620

Wang, F. X., Ma, Y. P., Yang, Ch. L, Zhao, P. M., Yao, Y., Jian, G.L., Luo, Y.M., \& Xia, G.X. 2011. Proteomic analysis of the sea-island cotton roots infected by wilt pathogen Verticillium dahliae. Proteomics, 22, 4296-4309. http://dx.doi.org/10.1002/pmic.201100062

Wargo, P. M. 1975. Lysis of the cell wall of Armillaria mellea by enzymes from forest trees. Physiological Plant Pathology, 5, 99-105.

Wiweger, M. M., Farbos, I., Ingouff, M., Lagercrantz, U., \& von Arnold, S. 2003. Expression of Chi4-Pa chitinase genes during somatic and zygotic embryo development in Norway spruce (Picea abies): similarities and differences betwen gymnosperm and angiosperm class IV chitinases. Journal of Experimental Botany, 54, 2691-2699. http://dx.doi.org/https://doi.org/10.1093/jxb/erg299
Xu, J., Xu, X., Tian, L. Wang, G., Zhang, X., Wang, X., \& Guo, W. 2016. Discovery and identification of candidate genes from the chitinase gene family for Verticillium dahliae resistance in cotton. Scientific Reports, 6: 1-12. http://dx.doi.org/10.1038/srep29022

Yun, D. J, D’Urzo, M. P., Abad, L., Takeda, S., Salzman, R., Chen, Z., Lee, H., Hasegawa, P. M., \& Bressan, R. A. 1996. Novel osmotically induced antifungal chitinases and bacterial expression of an active recombinant isoform. Plant Physiology, 111(4), 1219-1225.

Zhang, D., Hrmova, M., Wan, C. H., Wu, C., Balzen, J., Cai, W., Wang, J., Densmore, L. D., Fincher, G. B., Zhang, H., \& Haigler, C. H. 2004. Members of a new group of chitinase-like genes are expressed preferentially in cotton cells with secondary walls. Plant Molecular Biology, 54, 353-372. http://dx.doi.org/10.1023/B:PLAN.0000036369.55253.dd

Zur, I., Golebiowska, G., Dubas, E., Golemiec, E., Matušíková, I., Libantová, J., \& Moravč́ková, J. 2013. $\beta$-1,3-glucanase and chitinase activities in winter triticales during cold hardening and subsequent infection by Microdochium nivale. Biologia, 68, 241-248. http://dx.doi.org/10.2478/s11756-013-0001-0

Yokoyama, R., Nishitani, K. 2004. Genomic basis for cell-wall diversity in plants. A comparative approach to gene families in rice and Arabidopsis. Plant Cell Physiology, 45, 1111-1121. http://dx.doi.org/10.1093/pcp/pch151 